\title{
Angiokeratoma of Fordyce
}

\author{
Alexander K. C. Leung ${ }^{1 *}$ and Benjamin Barankin ${ }^{2}$ \\ ${ }^{1}$ Clinical Professor of Pediatrics, University of Calgary, Pediatric Consultant, Alberta Children's Hospital, Calgary, Alberta, Canada \\ ${ }^{2}$ Dermatologist, Medical Director and Founder, Toronto Dermatology Centre, Toronto, Ontario, Canada
}

\begin{abstract}
Angiokeratoma refers to a benign vascular telangiectasia in the papillary dermis that is associated with hyperkeratosis of the epidermis. Clinically, angiokeratoma of Fordyce presents as multiple, well-circumscribed, dome-shaped papules, sized 2 to $5 \mathrm{~mm}$ in diameter mainly on the scrotum. The lesions are usually bilateral. The color of the lesions may be red, blue, purple, dark red, or bluish-black. Newer lesions are often smaller, red, soft, compressible, and smooth while longstanding lesions are often larger, darker, firm, non-compressible, keratotic, scaly, and sometimes, warty. Most lesions are asymptomatic but irritation, pain, burning sensation, and itching may occasionally occur. Treatment is not required for the majority of patients with angiokeratoma of Fordyce apart from reassurance. For those who would like to have treatment for cosmetic reasons and for symptomatic lesions, treatment options include surgical excision, cryotherapy, electrocoagulation, sclerotherapy, and laser therapy.
\end{abstract}

\section{Introduction}

Angiokeratoma (derived from three Greek words meaning vessels, horn, and tumor, respectively) refers to a benign vascular telangiectasia in the papillary dermis that is associated with hyperkeratosis of the epidermis [1]. In 1896, John Addison Fordyce described the first case of localized angiokeratoma on the scrotum of a 60-year-old man [2]. The condition now bears his name.

\section{Epidemiology}

The prevalence of angiokeratomas is estimated to be approximately $0.16 \%$ among the general population $[3,4]$. Angiokeratoma of Fordyce accounts for $14 \%$ of all angiokeratomas [3]. The condition occurs predominantly in males. There is an increasing prevalence with age, from $0.6 \%$ of males aged 16 years to $16.7 \%$ of those over 70 years of age [5]. The disorder is most prevalent in Caucasians [3]. In the older age group, the condition may be associated with conditions with increased localized venous pressure such as varicocele, thrombophlebitis of the scrotum, and inguinal hernia [6]. However, in patients under the age of 20 years, usually no such association exists [6].

\section{Etiopathogenesis}

Presumably, the telangiectasia results from a loss or degeneration of the supportive elastic tissues in the walls of blood vessels, localized chronically increased venous pressure, or vascular malformation [1,7]. Predisposing factors include mechanical trauma and chronic irritation. The epidermal reaction such as acanthosis and hyperkeratosis may be associated with an expression of matrix metalloproteinase-9 localized in the epidermis just beneath the horny layer of the angiokeratoma [8]. Friction in an area close to the proximity of the vascular spaces may also have a role to play [9].

\section{Histopathology}

Histological findings include numerous, dilated, ectatic, thinwalled, congested blood vessels in the papillary dermis with overlying epidermal hyperkeratosis and acanthosis $[1,10]$.

\section{Clinical manifestations}

Clinically, angiokeratoma of Fordyce presents as multiple, wellcircumscribed, dome-shaped papules, sized 2 to $5 \mathrm{~mm}$ in diameter mainly on the scrotum. Rarely, the lesions can be found on the penile shaft, glans penis, inguinal folds, abdomen, buttocks, and upper thighs in males and on the vulva in females $[5,6,11]$. The lesions are usually bilateral, although unilateral angiokeratomas have rarely been reported [12]. The color of the lesions may be red, blue, purple, dark red, or bluish-black. Newer lesions are often smaller, red, soft, compressible, and smooth while longstanding lesions are often larger, darker, firm, non-compressible, keratotic, scaly, and sometimes, warty [13]. Confluence of telangiectases may lead to a red scrotum [7]. Most lesions are asymptomatic but irritation, pain, burning sensation, and itching may occasionally occur.

\section{Diagnosis}

The diagnosis is mainly clinical. The use of dermoscopy facilitates visualization of dark or red lacunae, whitish veil, peripheral erythema, and hemorrhagic crusts which are features of angiokeratomas [4]. A skin biopsy or referral to a dermatologist should be considered if the diagnosis is in doubt.

\section{Differential diagnosis}

Differential diagnosis includes melanocytic nevi, malignant melanoma, verruca vulgaris, condylomata acuminatum, verrucous

Correspondence to: Dr. Alexander K.C. Leung, Clinical Professor of Pediatrics, University of Calgary, Pediatric Consultant, Alberta Children's Hospital, \#200, 233-16 ${ }^{\text {th }}$ Avenue NW, Calgary, Alberta, Canada T2M 0H5, Tel: (403) 230-3322; E-mail: aleung@ucalgary.ca

Key words: angiokeratoma, scrotum, hyperkeratosis, dome-shaped papules, reassurance

Received: February 04, 2015; Accepted: February 14, 2015; Published: February 19,2015 


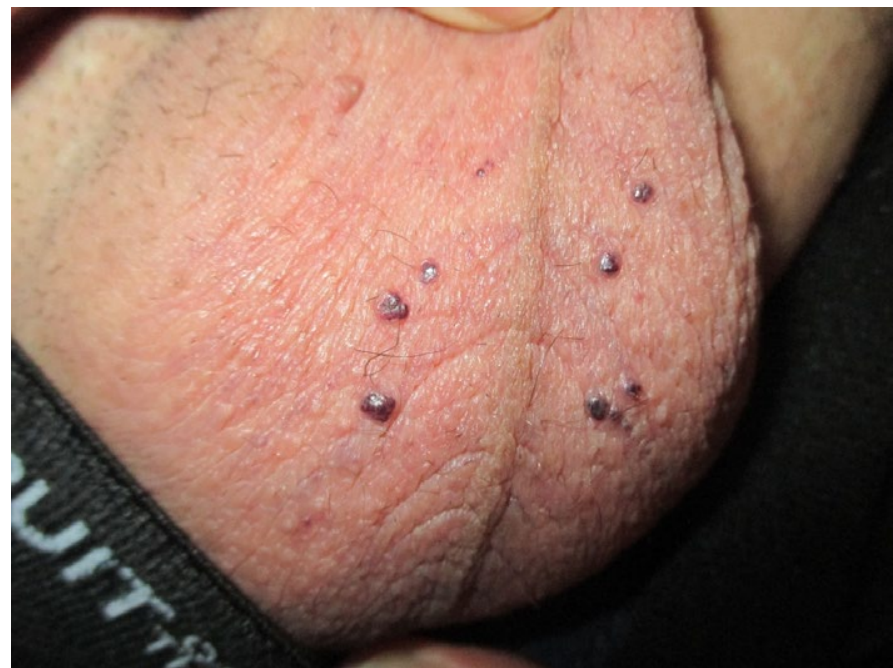

Figure 1. Angiokeratoma of Fordyce presenting as multiple, dark purple, discrete, domeshaped papules 2 to $3 \mathrm{~mm}$ in diameter on the scrotum of a 33-year-old man.

hemangiomas, hereditary hemorrhagic telangiectasia, lymphangioma circumscriptum, pigmented basal cell carcinoma, Spitz nevi, seborrheic keratosis, dermatofibromas, and pyogenic granuloma [1].

\section{Complications}

Rarely, the lesion may bleed during sexual intercourse or from scratching [14]. A hemorrhagic crust may develop [1,4]. Angiokeratomas are prone to thrombosis. Angiokeratoma of Fordyce can be cosmetically unsightly and may lead to anxiety and social embarrassment.

\section{Prognosis}

Without treatment, the lesions tend to persist and may increase in size and number with time [1]. Spontaneous regression is rare.

\section{Management}

Evidence of increased scrotal venous pressure such as varicocele and inguinal hernia should be sought; treatment of which may lead to regression of the angiokeratoma [13]. Otherwise, treatment is not required for the majority of patients with angiokeratoma of Fordyce apart from reassurance. For those who would like to have treatment for cosmetic reasons and for symptomatic lesions, treatment options include surgical excision, cryotherapy, electrocoagulation, sclerotherapy, and laser therapy $[1,15]$.

\section{References}

1. Eminger L (2012) Angiokeratomas Mibelli and Fordyce. In: Heyman WR, Anderson BE, Hivnor C, et al. (Eds.), Clinical Decision Support: Dermatology. Wilmington, Delaware: Decision Support in Medicine, LLC, 2012, electronic database. URL:http:// www.decisionsupportinmedicine.com.

2. Fordyce JA (1896) Angiokeratoma of the scrotum. J Cut Dis 14: 81-89.

3. Schiller PI, Itin PH (1996) Angiokeratomas: an update. Dermatology 193: 275-282. [Crossref]

4. Zaballos P, Daufí C, Puig S, Argenziano G, Moreno-Ramírez D, et al. (2007) Dermoscopy of solitary angiokeratomas: a morphological study. Arch Dermatol 143: 318-325. [Crossref]

5. Bechara FG, Jansen T, Wilmert M (2004) Angiokeratoma Fordyce of the glans penis: combined treatment with erbium: YAG and $532 \mathrm{~nm} \mathrm{KTP} \mathrm{(frequency} \mathrm{doubled}$ neodynium: YAG) laser. J Dermatol 31: 943-945. [Crossref]

6. Patrizi A, Neri I, Trevisi P, Landi C, Bardazzi F (1998) Congenital angiokeratoma of Fordyce. J Eur Acad Dermatol Venereol 10: 195-196. [Crossref]

7. Erkek E, Basar MM, Bagci Y, Karaduman A, Bilen CY, et al. (2005) Fordyce angiokeratomas as clues to local venous hypertension. Arch Dermatol 141: 1325-1326. [Crossref]

8. Sadana D, Sharma YK, Dash K, Chaudhari ND, Dharwadkar AA, et al. (2014) Angiokeratoma circumscriptum in a young male. Indian J Dermatol 59: 85-87. [Crossref]

9. Kandalgaonkar S, Tupsakhare S, Patil A, Agrawal G, Gabhane M, et al. (2013) Solitary angiokeratoma of oral mucosa: a rare presentation. Case Rep Dent 2013: 812323. [Crossref]

10. Trindade F, Torrelo A, Kutzner H, Requena L, Tellechea Ó, et al. (2014) An immunohistochemical study of angiokeratomas of children. Am J Dermatopathol 36: 796-799. [Crossref]

11. Pianezza ML, Singh D, Van der Kwast T, Jarvi K (2006) Rare case of recurrent angiokeratoma of Fordyce on penile shaft. Urology 68: 891. [Crossref]

12. Piqué-Duran E, Pérez-Cejudo JA, Cameselle-Martínez D, García-Vázquez O (2013) Unilateral angiokeratoma of Fordyce. Actas Dermosifiliogr 104: 163-164. [Crossref]

13. Jansen T, Bechara FG, Stücker M, Altmeyer P (2002) Angiokeratoma of the scrotum (Fordyce type) associated with angiokeratoma of the oral cavity. Acta Derm Venereol 82: 208-210. [Crossref]

14. Trickett R, Dowd H (2006) Angiokeratoma of the scrotum: a case of scrotal bleeding. Emerg Med J 23: e57. [Crossref]

15. Seo SH, Chin HW, Sung HW (2010) Angiokeratoma of Fordyce treated with $0.5 \%$ ethanolamine oleate or $0.25 \%$ sodium tetradecyl sulfate. Dermatol Surg 36: 1634 1637. [Crossref]

Copyright: (C2015 Leung AKC. This is an open-access article distributed under the terms of the Creative Commons Attribution License, which permits unrestricted use, distribution, and reproduction in any medium, provided the original author and source are credited. 